UDC 378.147-051:[005.963.3:004.946]:372.32

Veronika Denysenko, Nataliia Borysenko, Iryna Hrytsenko, Natalia Sydorenko

Kherson State University, Kherson, Ukraine

\title{
PREPARING THE FUTURE EDUCATOR TO THE CREATION OF AUGMENTED REALITY EXCURSIONS IN LOCAL EDUCATIONAL ENVIRONMENTS.
}

DOI: $10.14308 /$ ite 000736

The article highlights the peculiarities of future teachers' preparation for the organization of augmented reality virtual excursions in educational institutions. The pedagogical conditions of preparing the future teachers in higher education institutions for virtual tours as an important form of the educational process are substantiated. The pedagogical conditions and conducting such excursions of augmented reality in local educational environments are found out on the basis of $B Y O D$ concept. The differences, advantages and disadvantages of virtual, augmented and mixed reality excursions in the educational process of pedagogical institutions are also analysed. The ways of realization of the offered approach are presented, in particular creation of the routes of excursions in education by means of $Q R$ codes, which extends the boundaries of conducting excursions in space and in time, makes this form of training more flexible and systematic. The stages and peculiarities of creation the excursion routes in local environments of educational institutions were grounded, the method of diagnostics of certain aspects of students' knowledge about the conditions of the creation of virtual excursions in local educational environments is presented. Attention is paid to the importance of future teachers' media education as they will design the educational environments including modern informative and pedagogical innovations, and the logic of the evolutionary change of computerized textbooks and online educational resources for mobile learning is proved. The concept of augmented reality opportunities opens wide prospects for the introduction of learning innovations in all forms of educational process organization.

Keywords: augmented reality excursion, local educational environment, cloud technologies, mobile learning, BYOD concept, QR code

Problem statement in general. Nowadays society requires further expansion and deepening of education informatization which is caused not only by using the latest possibilities of information and communication technologies, but also by constant improvement of the effectiveness of training specialists with a qualitatively new type of thinking. In the context of this modernization the importance of media education increases for future teachers to design educational environment involving modern information and pedagogical innovations and to be able to fulfill educational tasks at the level of contemporary challenges.

The analysis of recent research and publications proves that such scientists as $O$. Barna, N. Balyk V. Bykov, Y. Mashbits, N. Morze, G. Shmyger, N. Gritsay etc. are engaged in digital and multimedia issues in the process of virtualization of pedagogical activity. The implementation of information and communication technologies into the educational process of educational institutions is covered by well-known scientists V. Bykov, A. Gurzhii, R. Gurevich O. Spivakovsky and others. Dissertation research of Y. Bulakhov, V. Ginger, K. Kirey, O. Strizhak, O. Tchaikovsky, I. Shakhin, L. Shevchenko, S. Yashanov and others are devoted to using the multimedia tools and technologies in pedagogical activity.The authors of modern scientific and pedagogical research focus on the high potential of multimedia resources (B. Trilling, D. Evans, A. Stepaniuk, I. Korobova, A. Lytvyn), psychological and pedagogical aspects of computerization of learning 
(T. Grizodub), using augmented reality applications in educational STEM projects (N. Balyk, G. Schmiger, etc.).

Some aspects of using information technologies in practice of primary education are explored in the works of O. Sukhovirsky, V. Shakotko, O. Shiman and others. In particular, the works of Y. Kazakov, L Shevchenko reveal the pedagogical conditions for the use of media education in the process of professional training of future teachers. Moreover, some practical experience of using multimedia is gained (M. Korzhos, L. Kravitskaya, D. Lemchuk, etc.) which testifies to the continuing interest of teachers in finding ways to use multimedia applications effectively: multimedia photo panorama, virtual laboratory, search engines (Wikimedia), Google, Galaxy, AltaWista, WebGrawler), teleconferences (usenet), access to news information resources, ability to publish voice information, create a homepage (homepage) and host it on the server, etc. Regarding the study of the prospects of development of information and communication technologies of teaching in Ukraine, the authors of the articles (O. Voronkin, T. Bondarenko, Y. Duchnych) are of the opinion that the continuous development of portable (mobile) computing devices creates prerequisites for their effective use in the educational process.

All this gives reason to claim that the problem of virtualization in education is actualand in the field of scientific interest of many scientists.

There are virtually no studies in the theory and methodology of professional education that highlight the methodological aspects of preparing students for virtual tours in local educational settings. Only in some publications there are the features of the use of hybrid learning technologies (V. Andrievska, T. Bondarenko, V. Kukharenko), virtual and augmented reality (E. Alexandrova, K. Veres, O. Korabin, O. Pidlinieva) and some aspects of development of electronic educational and methodological complexes in conditions of educational environment of modern school (S. Martyniuk, Y. Kulinka). In turn, A. Aleksiuk, S. Vitvitskaya, O. Bida, O. Savchenko and others devoted their academic studies to the problem of such organizational form of study as an excursion but in modern scientific publications we hardly find thorough research on virtual types of excursions and requirements for them. Some scientists (A. Gonchar, O. Kovalenko, I. Korzhos, M. Moskalenko, Y. Kulinka) consider the concept of "virtual excursion", give examples of such excursions but the question of virtualization of educational environments remains open.

Highlighting unresolved parts of the problem. Understanding education as a dynamic, ever-changing field of human life is logical and valid. Changes in how information is received should change the way it is used. The evolutionary change of computerized textbooks and online educational resources to mobile learning is observed [1].

The analysis of scientific literature and pedagogical experience show that the problem of creating virtual educational environments for excursions remains insufficiently practiced: the methodology of using Internet resources is not disclosed, there are not enough methodical manuals, recommendations, additional materials, material and technical support, etc. We state that issues related to the development and implementation of virtual excursions into the practice of the modern teacher and preparation of future specialists for this type of work remain unaddressed. Scientists do not distinguish the features, advantages and disadvantages of VR (virtual reality), AR (augmented reality) and MR (mixed reality) technologies in preparation and conducting virtual excursions.

Today the key stop factors that negatively influence the development of methodological aspects of the problem of implementation of virtual reality technologies are highlighted. They include: lack of high-quality VR and AR content, the cost of significant resources to create it, large investments in equipping study rooms, frequent updating of educational programs, lack of systematic training for future teachers, the use of special applications that may be useful in practice of elementary school teachers, namely: Trello, Documents ToGo, Easy Bib, Self Control, xMind, 3D Graphics, Geogebra, Duolingo, KAHOOT.

The analysis of online content showed that Google services (Gmail, Google Drive, Google Calendar, Google Maps, Google+ Hangouts, You Tube, Google Play, Google Keep, Picasa, Google 
Moderator, Google Blogger, etc.) are becoming widely used in educational activities. So, the iOS platform publishes experiments for children and adults that are regularly updated, with detailed instructions and clear explanations for each. All experiments are easy to perform and require no special skills, but of the 500 published applications only 50 are free.

The active use of devices and applications in the educational process is defined in information sources (V. Andrievska, T. Bondarenko, G. Kozhevnikov, G. Tkachuk) as a BYOD (Bring Your Own Device) trend. The use of mobile devices based on the BYOD concept enables the implementation of an educational and mobile learning environment. Mobile devices include iPhones, smartphones, tablets, etc. These devices work in operating systems (MaciOS, Android, Windows Phone, etc.), support work in mobile networks (preferably $3 \mathrm{G}$ and $4 \mathrm{G}$ generation) with Wi-Fi technology.

Creating a local information and educational environment based on the BYOD concept allows to expand the space and ensure control of the educational process not only within but also beyond the auditoriums. The authors (T. Bondarenko, G. Kozhevnikov) point out that the use of the BYOD concept as a universal educational tool enables the implementation of such principles of learning as clarity, accessibility, awareness, connection of learning with life; to develop the interest of the learners in the acquisition of knowledge; to promote their cognitive activity, initiative; to form the ability to pose problems and find ways to solve them. The fact that mobile applications can be used in the virtualization process of the educational environment is significant.

The concept of BYOD (support the use of personal devices in the educational process) has recently become more widespread. Thus, according to the study by ESET [16], education providers can work with the necessary resources using mobile devices. Users acquire mobility based on the implementation of Wi-Fi technology in educational institutions [3, 8, 13, 17, 18,19].

Therefore, the purpose of the article is to justify the pedagogical conditions of preparing the future teachers in higher education institutions for virtual tours as an important form of the educational process.

Presenting main material. The use of innovative technologies in education also implies an appropriate restructuring of the educational process. The main objective of educational institutions as local educational environments is to develop blended (hybrid) learning based on the BYOD concept $[3,6,8,15,16]$. It is necessary to focus the attention of pedagogical teams of higher education institutions on the individualization of learning, improving the quality of knowledge, the formation of competences, the ability to self-study and self-education of future teachers. At present, new skills of teachers must be formed and those the importance of which has significantly increased for the formation of professional competence of modern teacher should be developed: responsibility, tolerance, openness to questions, innovation, technological enthusiasm, curiosity and pedagogical technique [17].

Students should not only participate in the process of perception and learning, but also be able to creatively apply them, independently design the vector of their own development, to correlate the learning outcomes with the prospects of their own professional activity. But in spite of high demands, modern system of general and professional education demonstrates contradictions between the use of new tools and the inertia of constant stereotypes of learning. Modern authors (V. Andrievska, T. Bondarenko, V. Kukharenko, A. Lytvyn) of researching the innovative forms and teaching methods reduce the use of virtual education technologies only to such tools as electronic textbooks, test shells, multimedia materials, computer virtual simulators, unfortunately, they do not distinguish between virtual (VR - virtual reality), augmented (AR - augmented reality) and mixed (MR - mixed reality) reality, which combines the first two technologies.

We find it expedient to consider the semantics of the concept of "excursion", which is understood by modern scholars as both a form of work (excursion-consultation, excursion-demonstration, excursion-lesson, scientific excursion for a special audience), and as a method of teaching that promotes observational and independent skills. The word "excursion" (from 
Latin. excurro - run out) indicates that the training should be conducted outside the auditorium (in nature, in the museum, etc.). It is a form of organization of the educational process, which allows to organize the observation and study of various phenomena, objects, processes in natural conditions, in production, in cultural institutions, etc. [6,19].

Agreeing with the approach to the classification of classical excursions (O. Savchenko, O. Bida, N. Gritsay) and considering that in practice any division of excursions into clearly divided groups is rather relative, the theoretical classification allows to determine the approximate orientation of the excursion and to plan it in the most expedient way.

Didactic scientists determine different types of excursions depending on the following characteristics: the nature of the object (museum, natural, route, manufacturing), connection with the curriculum (program, non-program), volume (one-topic, multi-topic, complex and integrated), seasons (phenological), method of conducting (research, illustrative, combined), didactic goal (introductory, accompanying, final). Thematic excursions, in turn, are divided into historical (historical-local), archeological, ethnographic, military-historical, historical-biographical, excursions to historical museums, manufacturing, natural and ecological, art, literary, etc. [1, 6]. The dominant way of cognitive activity during a classical excursion is the direct perception of the objects of nature, the social world, their interconnections. During the excursion the teacher combines frontal work with group and individual work. The main method of cognition on the excursion is to observe the phenomena of nature, objects of cultural heritage, the obvious relationship between them.

As to the concept of "virtual excursion", according to Ch. Piercein the "Dictionary of Philosophy and Psychology" virtual X (where X is any common noun) is "a certain object that is not $\mathrm{X}$ but has an effect (lat. virtus - ability, ability) $\mathrm{X}$ "[14]. Multimedia virtual excursion is a software and information hypertext product for integrated presentation of excursion materials [14].

A virtual excursion is an organizational form of training that differs from a real excursion by virtual display of real-life objects (museums, parks, city streets, etc.) in order to create the conditions for independent observation, collecting the necessary facts [1]. Its benefits are emotional perception, accessibility, the ability to re-conduct, modify and transform. During the virtual excursion there is a transition from one panorama to another which is carried out through the active zones that are placed directly on the images. Virtual tours are based on spherical images that, unlike an ordinary photo, allow the object to be perceived from the middle. The panoramic image allows you to display reality more holistically than a series of scattered photos. All this can be supplemented by the sound of the foreground and background music, as well as regular photos, videos, flash videos, explanations, contact information, etc.

Another way to create a virtual educational journey is to do it through multimedia excursions that a teacher can develop himself. The advantages of it are that the teacher, like no one, understands the place and role of the thematic excursion in studying of the relevant topic of the subject; accurately presents requirements for images:scale, angle, sequence of shots, the necessity of simultaneous presence in the field of view of certain objects. Ideally, the teacher firstly develops a textual logical conceptual excursion model, and then creates a photo / video sequence that becomes an illustration, a visual proof of the key content components of the story.

Consider the features of conducting a virtual tour. The works of scientists (Osipova N., Kravtsov H., Hniedkova O,. Kovalenko O.) highlight the main advantages of using VR technologies in education: clarity and a high degree of detail, focusing and the ability to change the scenario of events [19]. Scientists determine that VR technologies and virtual reality systems are a high-tech didactic tool, they make essential specifics in teacher activities and require motivational readiness of participants in the educational process to use them [6].

VR Tours support programs are usually created on the same platforms as PC games are created (Unity, UnrealEngine, LABSTER, LECTUREVR, EligoVision, Easypano Studio 2005, 360 
Degrees Of Freedom Developer Suite 6.3, SP_VTB 4.10, SP_STITCHER 3.2, etc. ) and cannot be used by elementary school teachers to create virtual content.

Much easier is to use Google services (App Store, Google Play, Windows Phone Store) where teachers use a variety of ready-made virtual tours. Google Apps add more than 200 expeditions, ranging from the Great Barrier Reef in Australia to the ancient Machu Picchu ruins in Peru. The app is available for users of the Android mobile operating system, and Google is planning to launch it for iOS soon. (A.Lytvyn) [10]. Google Cultural Institute has been in existence for several years; it is a global educational online project and its partnership program brings together hundreds of museums, cultural institutes and archives around the world. All interactive exhibitions and online tours are spent in English. Thanks to technologies such as Picasa, App Engine and Street View, Google programmers have been able to systematize art objects from different museums around the world and create something more than just a set of reproductions. Google Academy unites several projects: the Art Project, the World Wonders Project, and the Archive Exhibitions. Google Art Academy's Virtual Project brings together 40,000 digitized copies of art, created by 6,000 artists, photographers, sculptors, etc. These works are physically located in 250 cultural institutions in 40 countries of the world, in well-known and small specialized museums. The range of materials contains photographs of drawings, watercolors, sculptures, artifacts [4].

Project Digital transformation of Ukraine has been in existence for several years; its main purpose is to attract investment and tourists to the regions with the help of modern internet tools. 4 regions have already become project participants: Rivne, Kherson, Odessa and Mykolaiv, as well as Lviv [12]. Within the project implementation more than 2,000 objects of social, tourist and public importance, 360-degree panorama-photosphere have been added to Google-Map of Lviv, as well as virtual Ostroh Academytours, Rivne Regional Museum of Local Lore. Lviv has the opportunity to virtually walk through the city parks, visit famous museums and cathedrals. Photos of such landmarks of Kherson region as Askania Nova, Oleshkovsky Sands Landscape Reserve, Sivash Lake, Biryuchi Island, Dzarylgach Island, Dniprovsky Plavni appeared on Google Maps. Teachers and students have the opportunity to join virtual tours within didactic tasks. Of course, virtual excursions have certain advantages: accessibility (the ability to view at any time), panorama, the ability to detail the image and use the tour according to the didactic tasks of the study topic. But there are some disadvantages: subjectivity (depending on the people who create the tour, lack of opportunity to ask questions in real time mode, limited impressions, depending on Wi-Fi networks. In addition, teachers can only use materials posted in networks, etc.

The use of augmented reality excursions has several advantages over traditional approaches: it helps to get acquainted with the methods of searching, organizing and visualizing of information with the help of ICT. During the excursion students not only interact with the objects of study, but also master practical skills of independent observation and analysis. Creating and conducting such excursions promotes the fastening of knowledge of modern computer and Internet technologies [5].

So, the leading role in organization of augmented reality excursion belongs to peoplebut multimedia technologies are only one of the possible means of its activation, they only complement it.

Robert Azuma defined augmented reality as "a system that combines virtual and real, interacts in real time and works in 3D" [1, p.22]. In other words, it is a fictional, imaginary object, subject, category, attitude, action, which are not present at this time in the real world, but created only in imagination, human thought, or modeled by other objects. In interactive mode of work graphics, animation, photos, video, sound, text are combined into an integrated information environment in which the user finds qualitatively new opportunities that can play the role of a powerful means of activating the educational and cognitive activity of pupils and students.

Using of augmented reality technology as a tool of active learning can be effectively used for visual demonstrations that allow students to immerse themselves in the process of studying and 
increase the level of assimilation of their learning material. AR-reality technologies are high-tech didactic tools that provide comprehensive developmental effect.

In the process of creating augmented AR-reality excursion scientists distinguish 3 stages: determining the purpose, objects and route of the excursion, searching for Internet resources (in the case of creating a guide and determining the URL), taking photos, processing of received images and creating a virtual journey according to excursion plan.

Exploring different aspects of this problem made it possible to turn to the tools of augmented AR-reality which the teacher can use according to the didactic tasks and technical capabilities of modern school. In our opinion, one of the tools that is appropriate to use while creating and conducting an AR reality tour is QR code (Quick Response) that gives you free access to global sources of information (video, audio, web sites and more).

The advantage of this type of tool is not only the ability to use QR codes, but also creating them and free downloading to Google Drive. Currently, there are many on-line services and applications, including https://qrcode.tec-it.com/en, https://www.qr-code.com.ua, https://qr9.me/free -qr-code-generator.php? lang $=u k$ and others to help students work out the content of the virtual excursion and to activate additional channels of information to take, to read information and store it in the memory of mobile devices.Easy scanning of QR code, creation of your own QR code and its distribution through social networks (Facebook, Twitter, etc.) among communication participants in the form of hyperlinks optimizes the process of organizing and conducting AR-reality tours. Using of QR code together with other BYOD tools gives you easy access to Google Maps with the ability to automatically search for objects, instantly locate your own location, GPS navigation, additional geo-information, etc; access to E-dictionaries, E-encyclopedias and other resources; work with Google Docs (view, edit, etc.), instant data capture, steps (dynamics) of work by creating screenshots from a display, such as YouTube channel or your own video, the ability to crop screenshots, add text, graphics, easy video making, taking photos that are automatically uploaded into a secure cloud storage, sorted and available for search immediately after uploading with full privacy. Besides, the convenient processing of video, photos with the help of advanced filtering features, the availability of convenient tools for adding text to photos and videos, the use of multifunctional training applications make it possible to create a unique digital educational space for organizing quality work of group during the excursion. The advantages of using QR code include: open online commenting; keeping interaction history; real time collaboration with team members or project members, regardless of positioning; implementation of operational communication through online survey in real time $[7,11]$.

Studying the peculiarities and conditions of organizing virtual excursions was realized in the educational environment of Kherson State University. According to the curriculum of the bachelor's degree of the specialities "012 Preschool Education", "013 Primary Education", excursion routes were developed around the territory of Kherson State University Botanical Garden and QR codes were created for plants of different biotic groups on Google Drive. QR codes were placed near the plants with links to web pages indicating botanical features of the objects and containing additional scientific information. The main requirement for the selection of photos and videos of the virtual excursion was the relevance of the theme "Plants-introductions of Kherson region": the frame and hyperlink reflect not only a certain number of species, but also the diversity of representatives of systematic groups of plants, introduced in the conditions of the most arid region of Ukraine - the Southern Steppe.

The fourth-year students independently created QR codes that can be read without Internet connection by using the special Class Tools.NET service.

Kherson State University Botanical Garden is a research center and educational base for the natural practice of various faculties. There is ongoing work on conservation and reproduction of endemic, rare and endangered plant species here. The result of this work is the garden "Kherson steppe" where they grow. The biological diversity of the Botanical Garden's collection is over 220 
species of woody plants, 200 species of herbaceous plants, 60 species of fungi, 21 species of lichens, 15 species of mosses. The Botanical Garden includes the following sites: the Big Botanical Circle, the Small Botanical Circle, the Linden, Oak and Chestnut Alleys, the New Arboretum, the Continuous Flowering Garden, the Kherson Steppe Research Area, the Oak and Pine groves (Fig. 1).

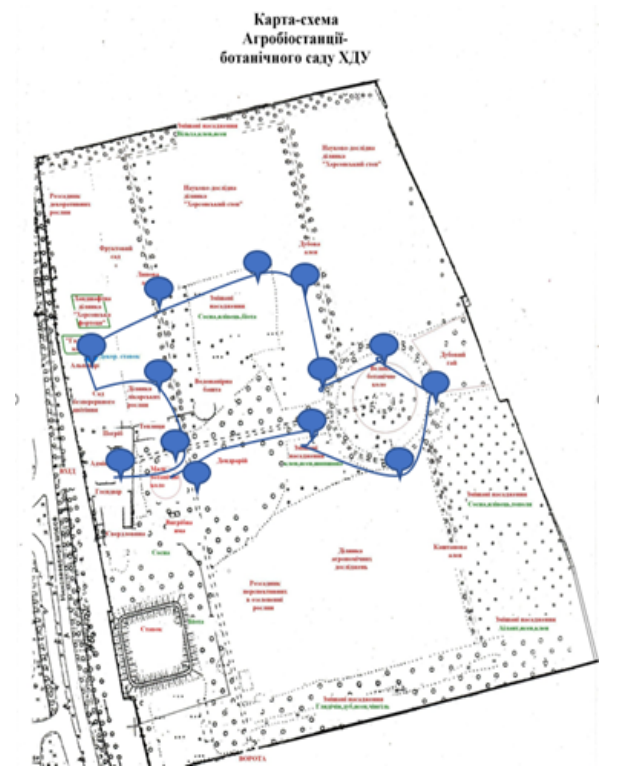

Figure 1. Map-diagram of Kherson State University Botanical Gardens with excursion route marked with QR-codes

The process of preparing the excursions included the choice of a theme, statement of a purpose and tasks, creation of a route, studying and selection of excursion objects, studying of literature on a theme of excursion, consultations with experts, writing the control text of the excursion, completing the "information case", choice of methods of conducting the excursion, drawing up a technological map. Students were guided by the general requirements for this type of activity:

- determine in advance the excursion object (media resource or set of media resources), identify educational opportunities, aesthetic significance;

- $\quad$ identify goals and objectives, prepare problematic questions for the group that will include elements of observation, research and practical work;

- $\quad$ find out the additional sources of information;

- $\quad$ make up an excursion plan and mark the "itinerary" using the information map;

- $\quad$ work out the organizational interview that defines excursion tasks, safety rules and behavior.

The excursions were conducted by the fourth-year students for freshmen in the presence of an independent expert (teacher) and followed by a self-analysis of the quality of conducting in the Google test forms at ksu.ks.ua. The site was developed with ASP.NET 2.0 technology and MS SQL Server 2005. The site is open to students who have been authorized and enrolled in a group by a teacher.

The site has the following functionality:

1. Adding and editing test questions divided into five categories for students by the teacher.

2. Passing tests on certain questions by students.

3. Display of statistical and graphical test results (personal for the student and all users for the teacher).

4. Downloading students' creative works in the gallery for evaluating by the students themselves. 
We distinguished the following indicators of the ability to organize and conduct the excursion: instrumental readiness, informational readiness, methodological readiness, ability to make a route, excursion time allocation

The answers to each question in the questionnaires were presented in the form: "yes", "sometimes", "no". Accordingly, in order to calculate the level of development of skills in general, each answer has got a point equivalent: "no" - 0 points; "sometimes" - 1 point, "yes"- 2 points. For comparative analysis of each indicator we calculated the total number of points obtained by each of the respondents and then determined the relative frequency or proportion of the indicator. The closed response form made it possible to automate the process of calculating the results and to carry it out using a computer.

Computer support for the diagnostics of indicators and criteria of the ability to conduct the excursion allowed: a) each student to get a picture of the formation of his knowledge, skills and personal characteristics at any time; reflect on the results obtained and determine the ways to eliminate the fixed shortcomings; b) the teacher to get a generalized information about the distribution of students to the levels of formation of these skills. The page interface is shown in Figure 2.
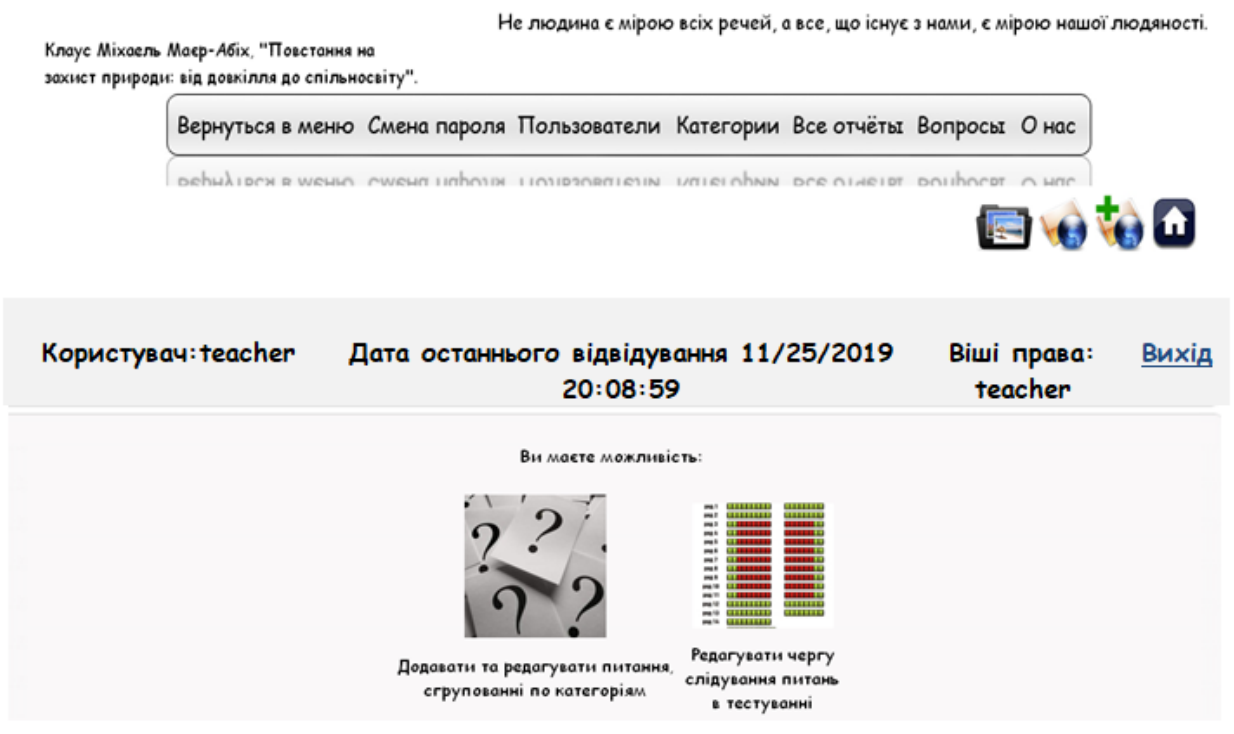

Figure 2. Website Teacher Page Interface

The advantage of the technique is the versatility, convenience and transparency in the diagnostics and processing of results. The obtained test results are available to both the teacher and the student in the form of a petal diagram (Fig. 3), which makes it possible to vary the test material regarding the assessment parameters. 


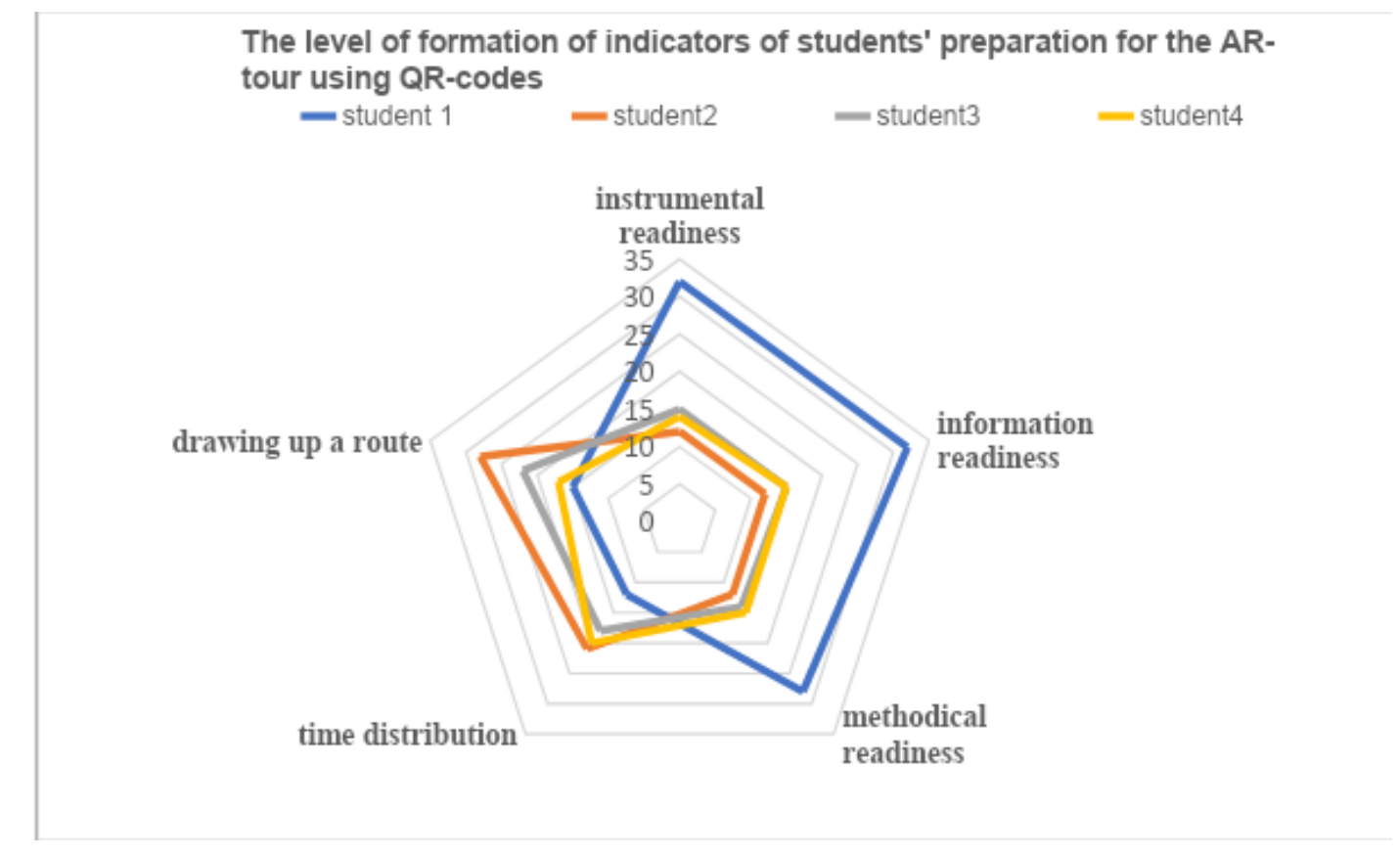

Figure 3. Fragment of the petal chart of the ability to conduct AR-trips using QR codes (4 of 40)

The test system gives opportunities to identify the basic level, possible ways, psychological and pedagogical conditions and means of effective formation of conducting AR-trips skills.

Creating the virtual excursion of augmented reality is a complex process that requires organizational efforts and certain pedagogical conditions. It is one of the most complex types of educational research work, the acquisition of which enables the integrated use of innovative teaching methods; broadens and deepens knowledge; shows the practical importance of knowledge; promotes acquaintance with the modern achievements of science and is the effective means of professional preparation of students for future professional activity. This approach to excursions equips modern school teachers with mobile learning tools that allow them to access educational content and organize productive tasks, conduct discipline quests, etc.

\section{Conclusions}

To sum up, pedagogical conditions for preparing the future educators to the creation of augmented reality virtual excursions in local educational environments were studied out. They include:

- $\quad$ students' motivational readiness to realize the opportunities of virtual excursion as the means of its intensification;

- orientation of goals and motives of future teacher's professional activity for self-improvement and application of multimedia technologies in professional activity in the conditions of the informative educational environment;

- $\quad$ development of IT skills for realizing virtual education opportunities;

- creative activity and independence of education recipients.

For successful learning in multimedia environment an educator should have a high level of intellectual development that is the basis for successful work with a multimedia product, broad cognitive interests, general erudition,sustained attention.

We believe that the following principles of organization of training are becoming especially relevant from the point of view of influence on the specified conditions of training of teachers, 
which determine the ability to conduct a virtual excursion in the informative educational environment of a higher education institution:

- the principle of predictability (prognosticity) that determines the establishment of sustainable links between educational content and current technological advances;

- the principle of technological adaptability and innovation;

- the principle of diagnostics, which allows determining the levels of achievement of educational goals and outlining the ways of development and content filling of future teachers' professional training.

\section{Prospects for further research}

In future it is planned to consider the suggested approach for using applications of augmented reality in other forms of educational activity in the system of retraining of educators. Concidering the limited resources available in the sphere of education, the concept of augmented reality opportunities opens wide prospects for the introduction of learning innovations in all forms of educational process organization, including conducting educational tours.

\section{REFERENCES}

1. Alexandrova, E. V. (2010). Virtual excursion as one of the effective forms of organization of educational process. History of Ukraine. 10, 22-24.

2. Andriyevska, V. M. (2017). The BYOD concept as a tool for implementing STEAM education. Physics and mathematics education, 4, 13-17. Access mode: http://nbuv.gov.ua/UJRN/fmo 201744

3. Bondarenko, T. S. (2016). Using the BYOD concept for testing the educational achievement based on Google search services. Information technologies in education, 2, 41-53. Access mode: http://nbuv.gov.ua/UJRN/itvo 2016 26

4. Virtual Museums: Google Cultural Institute. [Electronic resource]. Access mode: http://zillion.net/blog/264/virtual-nyie-muziei-google-cultural-institute.

5. Gonchar, A. V., Popova, M. A., Strizhak, A. E. (2019). Ontology of a 3D Panorama Tour of the Virtual Museum. Ecological safety and nature management, 1, 71-78. Access Mode: http://nbuv.gov.ua/UJRN/ebpk 2019199

6. Kovalenko, O. V. (2019). Using the virtual excursions as modern forms of organization of educational process. Innovative pedagogy: scientific journal, 9, 94-97. Access mode: http://repository.sspu.edu.ua/handle/123456789/7152

7. Korzhos, I. M. (2016). Virtual excursions in Science and Biology for 6-7 grades of intensive pedagogical correction. City Exhibition of Pedagogical Technologies. Zaporizhzhia. Access mode: http://pedvistavka.at.ua/publ/kompetentnisna osvita/khimija biologija_ekologija/

8. Kukharenko, V. About mixed (hybrid) teaching [Electronic resource]. Access mode: http://kvn-e-learning.blogspot.com/2014/06/blog-post.html

9. Kulinka, Y. (2015). Preparing students for virtual tours at the labour training (technology)lessons. Psychological and pedagogical problems of rural school. 52, 44-50.

10. Lytvyn, A.V., Litvin, A. G. (2010). Media education as a component of information training of future specialists. Headmaster, 21, 1-5. Access mode: http: //prostir.museum/ - portal "Museum space of Ukraine" - Access mode: https: //museums.authenticukraine.com.ua/en /https://naurok.com.ua/post/8-variantiv-nezabutno-virtualno-ekskursi

11. Narimanova, E. V., Ermakov, V. A. (2015). Digital watermark method for QR code protection. Increasing resistance to non-affine transformations. Proceedings of the Military Institute of Taras Shevchenko National University of Kyiv, 50, 231-236. Access mode: http://nbuv.gov.ua/UJRN/Znpviknu $2015 \quad 50 \quad 39$.

12. Unknown Ukraine: Google virtual tours. [Electronic resource]. Resource access mode: http://igate.com/news/15331-neizvestnaya-ukraina-virtualnye-ehkskursii-ot-google 
13. Duchnich, Y., European Training 2020. Access mode: http://www.smart-edu.com/learning-in-europe-2020.html

14. Shaev, Yu. M. (2015). To the Question of the Semiotic Structure of Virtual Reality. Fundamental Research, 2-9, 2036-2040. Access mode: http://www.fundamental-research.ru/en/article/view? id=37357

15. Evans, D. What is BYOD and why is it important? [Electronic resource] / TechRadar / The home of technology. Access Mode: http://www.techradar.com/news/computing/what-is-byod-andwhy-is-it-important--1175088

16. BYOD Infographic [Electronic resource] / [ESET] / Access Mode: https://eset.co.th/abouteset/press-center/article/byod-infographic-for-security-its-not-a-pretty-picture / Creative Commonsblog [Electronic resource]. Access mode: https://creativecommons.org/2019/04/30/cc-search-images/

17.Modern Teaching Skills [Electronic resource]. Access mode:
https://www.examtime.com/blog/teaching-skills/

18. New Horizon Report Insists Teachers Use Tech. Access Mode: http://gettingsmart.com/2014/06/new-horizon-report-insists-teachers-use-tech/

19. Osipova, N., Kravtsov, H., Hniedkova, O., Lishchuk, T., Davidenko, K. Technologies of virtual and augmented reality for high education and secondary school. Access mode: http://ceur-ws.org/Vol-2393/paper_258.pdf

Денисенко В. В., Борисенко Н. М., Гриценко І. В., Сидоренко Н. І.

Херсонський державний університет, Херсон, Україна

ПІДГОТОВКА МАЙБУТНЬОГО ПЕДАГОГА ДО СТВОРЕННЯ ЕКСКУРСІЙ ДОПОВНЕНОЇ РЕАЛЬНОСТІ В ЛОКАЛЬНИХ ОСВІТНІХ СЕРЕДОВИЩАХ

У статті висвітлено особливості підготовки майбутніх педагогів до організації віртуальних екскурсій доповненої реальності в освітньому процесі закладів освіти. Обгрунтовано умови підготовки майбутніх педагогів до віртуальних екскурсій як важливої форми освітнього процесу. 3'ясовано педагогічні умови проведення та розробки екскурсій доповненої реальності в локальних освітніх середовищах на основі концепції BYOD. Також виділено відмінності, переваги та недоліки екскурсій віртуальної, доповненої та змішаної реальності в освітньому процесі педагогічних закладів. Наведено шляхи реалізації запропонованого підходу, зокрема створення маршрутів екскурсій в освітньому просторі за допомогою QR-кодів, що розширює межі проведення екскурсії у просторі й у часі, робить цю форму організації навчання більш гнучкою і систематичною. Обгрунтовано етапи та особливості створення маршрутів екскурсій в локальних середовищах закладів освіти, подано методику діагностики окремих аспектів знань студентів про умови створення віртуальних екскурсій в локальних освітніх середовищах. Акцентовано увагу на значущості медіаосвітньої підготовки майбутніх учителів, покликаних проектувати освітні середовища із залученням сучасних інформаційних, педагогічних інновацій та доведено логічність еволюційної зміни комп'ютеризованих підручників та мережевих освітніх ресурсів на мобільне навчання. Концепція можливостей доповненої реальності відкриває широкі перспективи для впровадження навчальних інновацій у всі форми організації освітнього процесу.

Ключові слова: екскурсія доповненої реальності, локальне освітнє середовище, хмарні технології, мобільне навчання, концепція BYOD, QR-код

Стаття надійшла до редакції 01.11.2020

The article was received 01 November 2020 